\title{
Factors Determining Willingness to Adopt Islamic Leadership Styles in the Case of Malaysian Accountants
}

\author{
Nurjeehan Binti Ayub, Hanudin Amin, Fitriah Ab Rahim
}

\begin{abstract}
The Prophet Muhammad (P.B.U.H) is the greatest leader of all times and he is an exemplary example of the best governmental leaders that is ever witnessed by the world and even after his death, his influence is still extending, powerful and pervasive. This paper is aimed at examining the factors determining the willingness to adopt Islamic leadership styles among Malaysian accountants in which five variables which are attitude, subjective norms, perceived behavioral control, perceived vicegerency, and perceived accountability personality are examined. Partial least squares (PLS) approach is employed to test the research hypotheses. The results obtained suggest that attitudes, subjective norms, perceived behavioral control, and perceived vicegerency are important in determining the willingness to adopt Islamic leadership styles among Malaysian accountants. Limitations and potential future research are provided.
\end{abstract}

Index Terms: Islamic leadership style; Malaysian accountants; Theory of planned behavior

\section{INTRODUCTION}

As human being, we are unable to do something alone and therefore there is a need for us to have cooperation with each other. Thus, the concept of cooperation brings out the ideas of leadership in our society. Every organization or group of people needs a good leader to achieve the desired success. Currently, the concept of leadership has become very crucial in influencing the political, financial and social areas from smaller institution like families to and even larger organization, require a good leaders in order to manage the affairs entrusted to them. Islam does not leave this issue unturned. In Islam the concept of leadership is discussed clearly especially on the concept and leadership style. In Islam leaders are individuals who have vision and objective and these people are predicted to always perform in a manner that are constant to Shariah (Islamic) law.

In accounting scandals, an increasing number of problems and critical issues especially issues related to integrity and

Revised Manuscript Received on September 22, 2019

Nurjeehan Binti Ayub, Labuan Faculty of International Finance, Universiti Malaysia Sabah Kampus Antarabangsa Labuan (UMSKAL), Jalan Sungai Pagar, 87000 Wilayh Persekutuan Labuan Malaysia., nurjeehana@ums.edu.my

Hanudin Amin, Labuan Faculty of International Finance, Universiti Malaysia Sabah Kampus Antarabangsa Labuan (UMSKAL), Jalan Sungai Pagar, 87000 Wilayh Persekutuan Labuan Malaysia.

Fitriah Ab Rahim, Labuan Faculty of International Finance, Universiti Malaysia Sabah Kampus Antarabangsa Labuan (UMSKAL), Jalan Sungai Pagar, 87000 Wilayh Persekutuan Labuan Malaysia.

transparency in accounting profession has made ethics a major concern and this is an important things that need to be taken seriously. In many cases, the unethical practice in accounting profession, has led to the failure of accounting practices and people now are reducing their level of trust towards the professions. (Low, Davey, \& Hooper, 2008). (Amin, Abdul-Rahman, \& Abdul-Razak, 2013) noted that accountants public image in accounting profession has made them the trustees in providing the truth and fair view of financial report. Therefore, they are expected to avoid any ethical issues pointed to them mainly issues that can increase the level of distrust among the accountants (Keller, Smith, \& Smith, 2007). (Kannaiah \& Kumar, 2017) also agreed that as an accountant, they need to have a strong ethics especially on their profession to verify the validity and value of quality of the financial reports. However, accounting scandals and frauds are always in the news every day and people from other professions are always willing to attack the accounting profession with these ugly happenings. The role of accountants in combating fraud should not be taken away. All accounting hands must be on the deck to cope with this challenge. Therefore, by practicing Islamic leadership style among accountants, can lead them to improved and profound cohesion and brotherhood.

Against this backdrop, this study is conducted to determine the effects of attitude, subjective nom, perceived behavioral control, perceived vicegerency and perceived accountability on willingness to adopt Islamic leadership styles. Following this objective, we develop these research questions as follows:

1. Is there any relationship between attitudes and willingness to adopt Islamic leadership styles?

2. Is there any relationship between subjective norms and willingness to adopt Islamic leadership styles?

3. Is there any relationship between perceived behavioural control and willingness to adopt Islamic leadership styles?

4. Is there any relationship between perceived vicegerency and willingness to adopt Islamic leadership styles?

5. Is there any relationship between perceived accountability and willingness to adopt Islamic leadership styles? 


\section{THEORETICAL FRAMEWORK}

The theoretical framework used in conducting this study are theory of planned behaviour (TPB) (Ajzen, 1991). This theory conclude that attitudes, subjective norms, perceived behavioral control(PBC) will lead to the behavioral intentions (Ajzen 1991).

Previous studies proved that this model can be used in an explaining intention behavior from various perspectives of studies (Amin and Abdul-Razak 2014; Ang et al., 2015; Awa et al., 2015; Gopi and Ramayah 2007; Hsiao and Tang 2014). For instance, from internet stock trading perspective, study from Gopi and Ramayah (2007) found that attitude, subjective norm and perceived behavioural control has a significant relationship towards behavioural intention to use internet stock trading.

In relation to this study, attitudes refer to the attitudes of Malaysian accountants in adopting Islamic leadership styles while subjective norms referring to the Prophet Muhammad (P.B.U.H) as an exemplary example of the best governmental leaders. In this study, perceived behavioral control are examining the ease or difficulty in adopting the Islamic leadership style In order to test the adoption of Islamic leadership styles, study extend the theory and adding the new variables, which are perceived vicegerency and perceived accountability. In this research, perceived vicegerency are known as a belief that acts or behaviour of being a servant and a caliph are met when he is implementing Islamic leadership styles in his administration and management duties. Perceived accountability that we are aimed at investigating is in adopting Islamic leadership style, a leader is willing to accept responsibility in leading and guiding their workers, able to make decisions, and can act on behalf of them (Alexakis, 2011).

In this study, we expect that attitudes, subjective norms, perceived behavioral control, perceived vicegerency and perceived accountability are the important antecedents that could positively influence willingness to adopt Islamic leadership styles among Malaysian accountants. Hence, the following hypotheses are proposed:

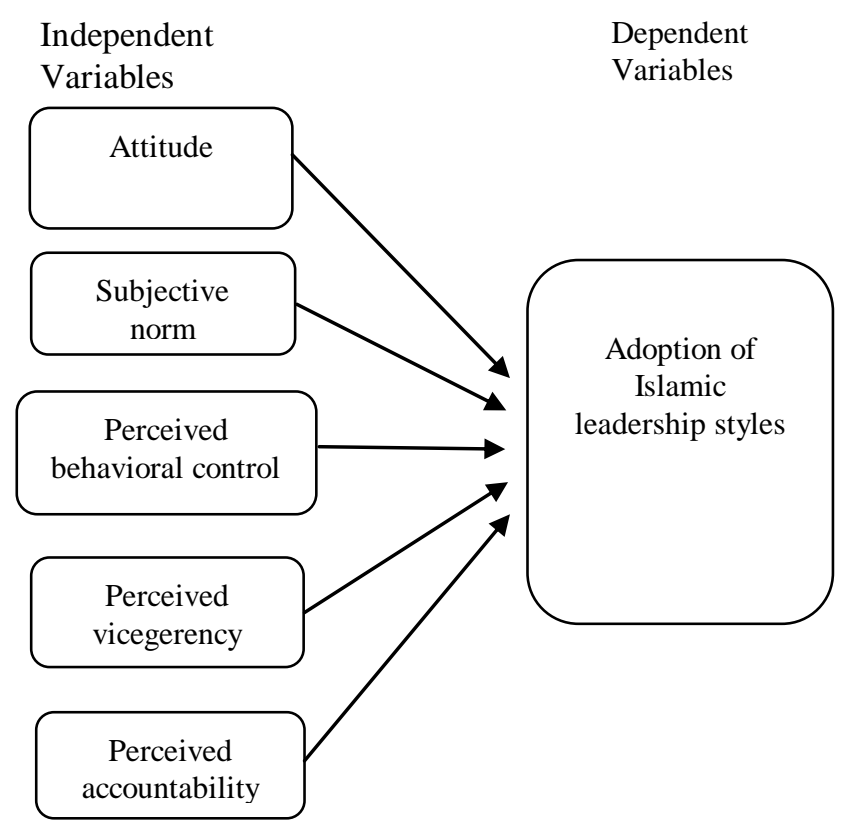

Fig 1: The Research Framework
H1: There is a significant relationship between attitude and willingness to adopt Islamic leadership style.

$\mathrm{H} 2$ : There is a significant relationship between subjective norms and willingness to adopt Islamic leadership styles.

$\mathrm{H} 3$ : There is a significant relationship between perceived behavioral control and willingness to adopt Islamic leadership styles.

H4: There is a significant relationship between perceived vicegerency and willingness to adopt Islamic leadership styles.

H5: There is a significant relationship between perceived accountability and willingness to adopt Islamic leadership styles.

\section{LITERATURE REVIEW}

\section{A. Islamic Leadership Style}

In Islam, Islamic leadership style able to influence their member's attitude and behavior and lead to organizations achieve the objectives. In order to achieve organization objectives, leader must be able to guide, and be visionary leader to lead organization to success. Leaders also should be able to lead, inspire, coaching and shared the vision to their followers.

From the Islamic leadership perspective, Quran and Hadith became as their source for continuous guidance (Ahmad \& Ogunsola, 2011a). In Islam, leaders are not free to act as they like, they are required to obey to any laws from Allah. Allah says:

And We made them leaders guiding men by Our command and We sent inspiration to do good deeds, to establish regular prayers, and to practice regular charity; and they constantly served Us only (Surah Al-Anbiya', [21] 73)

(Ahmad \& Ogunsola, 2011b) explained that leadership during the government of Prophet's (SAW) and the four caliphs' reign are based on religious and moral spirit which is fear to Allah. These features lead the leaders to do only activities that favored God. Humans are slaves who are only do actions that are commanded by God. (Ather \& Sobhani, 2009).

In Islam trust (Amanah) represent leadership. According to Salie (2008), trust in leadership refer to an agreement between leaders and their followers. Leaders promised to their followers that they will put their full effort in guiding, protecting and treating them justly all of which are for the sake of Allah and human kind.

\section{B. Attitude}

Attitude is another elements that lead to intention that ultimately lead to a particular behavior (Ang et al., 2015; Gopi and Ramayah 2007; Jin and Kang 2011). Attitude is referred to as a person's like or dislike in performing a certain task and their evaluation on a specific behaviour (Ang et al., 2015). From perspectives of this study, attitudes refer to the attitudes of Malaysian accountants in adopting Islamic leadership styles. 
In general, person tend to have the intention to perform certain behaviour when they have a positive attitude toward behaviour and vice versa. Attitude plays the important roles in an influencing customers' intention towards certain behaviour. Relationship between "attitude" and "intention" has been proofed in a variety research area (Ang et al., 2015; Jin and Kang 2011; Norazah and Norbayah 2015; Reza Jalilvand and Samiei 2013). For instance, a study by Norazah and Norbayah (2015) proven that attitude is the significant factors influencing customers intention to stay at a green hotel. Similarly, attitude is found to be significant in consumer's intention to visit halal store (Mohd Suki and Abang Salleh, 2016). However, contradict from previous findings, studies from (Asnawi et al., 2018; Wang et al., 2008) found insignificant relationship between attitude and individual's intention behaviour.

\section{Subjective Norm}

Subjective norm is a direct elements of behavioral intention (Ajzen, 1991). Subjective norm defined as expectation to comply with assumption that individual's intentions to perform that particular behavior are influence by others. (Alam et al., 2011). This can come from the influences of family members, friends, colleagues, organization and communities (Norazah and Abang Sulaiman 2016). Hence, in this study, subjective norm can influence willingness to adopt Islamic leadership styles.

Previous studies documented significant relationship between subjective norm and intention behavior among individuals (Ab Rahim and Amin 2011; Gopi and Ramayah 2007; Hsiao and Tang 2014; Jin and Kang 2011; Kumar 2017; Mohd Suki and Abang Salleh, 2016). For instance, an interesting study done by Alam and Sayuti (2011) found that there is a significant direct relationship between subjective norm and customer's intention to purchase halal food. However from different perspectives, studies from (Asnawi et al., 2018; M.S. Norazah \& Norbayah, 2015) stated an insignificant relationship occurs in both subjective norm and intention to consume halal product in international chain restaurant.

\section{Perceived Behavioral Control}

Perceived behavioural control is the individual's perception of the ease or difficulty in performing the behaviour of interest (Ajzen, 1991). In this study, PBC are the ease or difficulty in adopting the Islamic leadership style.

Previous studies has noted that there exist a positive relationship between $\mathrm{PBC}$ and individual's intention (Adnan, and Md Nordin 2017; Alam and Sayuti 2011; Gopi and Ramayah 2007). One of the interesting study from Alam and Sayuti (2011) found that PBC is significantly associated with the consumer purchase intention. From different perspective, study from Jin and Kang (2011) also found that PBC is one of the important factors in an influencing consumers' purchase intention of China consumers toward a US apparel brand.

Islam is a religion of peace and justice. By practicing the characteristics of Islamic leadership, in the form of leakage, abuse of power will be overcome and leaders themselves are the responsible person in ensuring that the system under his leadership runs smoothly without any manipulation.

\section{E. Perceived Vicegerency}

Vicegerency also means khalifah. Islamic leadership is the application of Khalifah in an organization. Based on the Islamic teaching, individuals or leader viewed their work as worship, and will do the best as they can in an implementing their duties (Beekun \& Badawi, 1999). In this research study, perceived vicegerency means an individual belief that his acts of being a servant and a caliph are met when he is implementing Islamic leadership styles in his administration and management duties. In Islam, a khalifa is said to be vicegerent when they can continues to practice the characteristics of Islamic leadership style. In fact, they believed that imaan are the main priority construct in each and every decision making and the system brought into the leadership are also known as mushawarah. (Salie, 2009).

\section{F. Perceived Accountability}

Islamic leader serve their followers or subordinates based on the Islamic principles. Accountability is one of the principles that need to adhere by Islamic leaders. In Islam, accountability is the vital component in management. Leaders must be accountable for their duties and responsibility (Ather \& Sobhani, 2008). Punishment and reward are for everyone who are responsible for any right or their wrong doing. Allah says:

"...whosoever does good equal to the weight of an atom (or a small ant) shall see it. And whosoever does evil equal to the weight of an atom (or a small ant) shall see it." (Surah Az-Zilzal,Verse- 7-8 ).

Accountability is the critical principles in Islam. Accountability focuses on what the individuals has done based on their responsibilities and duties. Leader's action are very important especially in guiding and protecting their followers. In applying the accountability concept, leaders are accountable for any duties and not to easily finger pointing their followers. In Islamic teaching, on the Day of the judgment, everyone will judge based on what they did. (Beekun, 2012). 'Adi bin 'Amira al Kindi has noted in the hadith which stated that:

I heard the Messenger of God (p) say: "Whose from you is appointed by us to a position of authority and he conceals from us a needle or something smaller than that, it would be misappropriation (of public funds), and hewill (have to) produce (it) on the Day of Judgment.[20]"

Lack of accountability among the leaders leads to the major scandals in management such as scandal like Enron, where management involved in unethical behavior because of lack of accountability. As a leader with Islamic leadership styles, they are expected to ensure that they are going to be responsible in leading and guiding their workers. From the context of this study, perceived accountability is when individuals manage to do their duties and responsibilities based on the justice, integrity and trustworthiness principles.

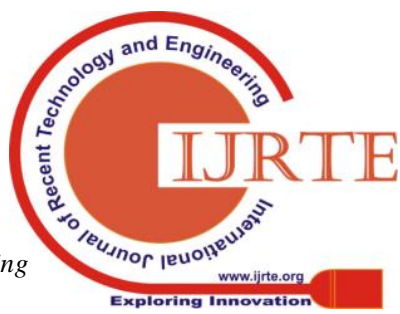




\section{G. Willingness To Adopt Islamic Leadership Styles}

Study in adoption of Islamic leadership styles receives lack of attention from previous research (Ahmed Haj Ali et al., 2018; Habib Rana and Shaukat Malik 2016; Hage and Posner 2015). For instance, a study from Ahmad and Fontaine (2011) examines the leadership approach among management International Islamic University Malaysia and which approach their staff prefer. Result shows that administrative employees prefer to adopt servant leadership as compared to transformational leadership. Study also found that respondents dislike transactional leadership. Further, from the study authors argues that servant leadership are similar to Islamic leadership. Hence, due to the lack of attention from previous researchers in Islamic leadership adoption, study try to fill the gap by examining intention to adopt Islamic leadership styles among accountants in Malaysia.

In Islam, when leaders practiced the rules of maqasid syar'iah (purpose or meaning required by syarak which must be tried to achieve) such as maintaining the religion, life, intellect, heredity and wealth. Thus, by applying all the concepts, this could help them to avoid themselves in any wrong doing and emphasizing what is suggested in Islam (Beekun, 2012).

\section{METHODOLOGY}

The unit of analysis of this work is Malaysian accountants. 180 respondents were selected and questionnaires are distributed to selected accounting firms. However, only 156 questionnaires are usable. This study also uses primary source of data collected using Google form as an online tools by generating a survey link. In this study, a five (5)-point Likert scale was applied in all section of questionnaires except for demographic background of respondents. Purposive sampling which are also known as judgmental sampling are being used in this study in which the respondent selected has an intention to adopt Islamic leadership style and the selected respondent also has a knowledge on the Prophet Muhammad (P.B.U.H) leadership style. The detail of the 5-point Likert scale measurement is shown in Table 1 below.

Table 1: Measurement of 5-point Likert Scale

\begin{tabular}{ll}
\hline Code & Description \\
\hline 1 & Strongly disagree \\
2 & Disagree \\
3 & Slightly agree \\
4 & Agree \\
5 & Strongly agree \\
\hline
\end{tabular}

In order to measure the independent variables, this study adopted the work of (Flowers, Freeman, \& Gladwell, 2017) by using 15 items and the response scale based on fiveLikert scale and in order to measure the dependent variable, this study adopted the work of (Ahmed, Farzeen, \& Anwar, 2017) by using only 5 items and the response scale based on five- frequency Likert-typed scale.

\section{RESULTS AND FINDINGS}

Table 1 provides the overall breakdown of the sampled respondents. The sampled respondents comprise $30.8 \%$ male and $69.2 \%$ female, $57.7 \%$ of the respondents are muslims while $42.3 \%$ of the respondents are non-muslims. Most of the respondents obtained their own degrees $91.7 \%$, contributed largely to the feedback for this work. The details are provided.

Table 1: Demographic

\begin{tabular}{lll}
\hline $\mathrm{N}$ & & Percentile \\
o. & & \\
\hline 1. Gender & Male & $48(30.8 \%)$ \\
2. Age & Female & $108(69.2 \%)$ \\
& Less than 20 & $0(0 \%)$ \\
& $21-30$ & $46(29.5 \%)$ \\
& $31-40$ & $108(69.2 \%)$ \\
3. Ethnic & M1-50 & $2(1.3 \%)$ \\
& Malay & $78(50 \%)$ \\
& Aboriginal & $25(16 \%)$ \\
& (Sabahan) & \\
& Aboriginal & $3(1.9 \%)$ \\
& (Sarawak) & \\
& Chinese & $39(25 \%)$ \\
& Indian & $11(7.1 \%)$ \\
4. Education & STPM & $1(0.6 \%)$ \\
attained & & $6(3.8 \%)$ \\
& Diploma & $143(91.7 \%)$ \\
& Degree & $6(3.8 \%)$ \\
& Master & $90(57.7 \%)$ \\
5. Religion & Muslim & $66(42.3 \%)$ \\
& Non-muslims & \\
\hline
\end{tabular}

\section{A. Measurement Model}

Following Ringle et al. (2005), we employ SmartPLS2.0 M3 in order to examine the research data and for that the inferences are drawn. On the same note, Chin, 2011 two-stage approach is used. This covers two stages namely (the first stage) measurement model and (the second stage) structural analysis. Table 2 shows that all factor loadings for the dimensions are greater than the recommended value of 0.7 , implying their acceptability and confirmation on discriminant validity. As learned from Table 2, this indicates the appropriateness of the battery items to represent the constructs under contemplation.

Table 2: Factor analysis

\begin{tabular}{|c|c|c|c|c|c|c|}
\hline $\begin{array}{l}\text { Battery } \\
\text { items }\end{array}$ & ATD & SBN & BC & $\mathrm{V}$ & PA & INT \\
\hline ATD1 & 0.9414 & 0.3062 & 0.4795 & $\begin{array}{c}0.432 \\
1 \\
\end{array}$ & 0.4523 & \begin{tabular}{|c}
0.309 \\
9 \\
\end{tabular} \\
\hline ATD2 & 0.797 & 0.4007 & 0.5181 & \begin{tabular}{|c}
0.523 \\
3 \\
\end{tabular} & 0.4488 & \begin{tabular}{|c|}
0.417 \\
8 \\
\end{tabular} \\
\hline ATD3 & 0.9058 & 0.4587 & 0.4066 & \begin{tabular}{|c|c|}
0.340 \\
4
\end{tabular} & 0.422 & $\begin{array}{c}0.475 \\
9 \\
\end{array}$ \\
\hline ATD4 & 0.8972 & 0.3736 & 0.3558 & \begin{tabular}{|c|c|}
0.451 \\
8 \\
\end{tabular} & 0.5135 & 0.34 \\
\hline ATD5 & 0.9014 & 0.3556 & 0.3671 & \begin{tabular}{|c}
0.489 \\
6 \\
\end{tabular} & 0.4603 & \begin{tabular}{|c|}
0.333 \\
3 \\
\end{tabular} \\
\hline SBN1 & 0.4775 & 0.8894 & 0.4572 & & & $\begin{array}{c}0.352 \\
8\end{array}$ \\
\hline
\end{tabular}




\begin{tabular}{|c|c|c|c|c|c|c|}
\hline SBN2 & 0.34 & 0.8895 & 0.4417 & $\begin{array}{c}0.482 \\
6\end{array}$ & 0.4082 & $\begin{array}{c}0.361 \\
3\end{array}$ \\
\hline SBN3 & 4099 & 0.878 & 0.4477 & $\begin{array}{c}0.417 \\
8 \\
\end{array}$ & 0.4354 & $\begin{array}{c}0.488 \\
9 \\
\end{array}$ \\
\hline SBN & 3652 & 0.9077 & 0.3647 & $\begin{array}{c}0.328 \\
7 \\
\end{array}$ & 0.5396 & $\begin{array}{c}0.353 \\
3 \\
\end{array}$ \\
\hline SBN5 & 233 & 004 & 0.3225 & 0.492 & 5237 & $\begin{array}{c}0.313 \\
5 \\
\end{array}$ \\
\hline $\mathrm{BC} 1$ & 4573 & 0.4917 & 0.9433 & $\begin{array}{c}0.559 \\
9\end{array}$ & 0.4249 & $\begin{array}{c}0.499 \\
1\end{array}$ \\
\hline $\mathrm{BC} 2$ & 4449 & 0.4872 & 0.9065 & $\begin{array}{c}0.523 \\
5 \\
\end{array}$ & 0.4658 & $\begin{array}{c}0.473 \\
7 \\
\end{array}$ \\
\hline BC3 & 4963 & 0.3157 & 0.9477 & $\begin{array}{c}0.411 \\
8 \\
\end{array}$ & 0.4545 & $\begin{array}{c}0.354 \\
7 \\
\end{array}$ \\
\hline BC4 & 655 & & 09 & 0.432 & 0.3819 & $\begin{array}{c}0.351 \\
8\end{array}$ \\
\hline BC5 & 3125 & 0.4837 & 0.9169 & $\begin{array}{c}0.410 \\
8 \\
\end{array}$ & 0.4395 & $\begin{array}{c}0.339 \\
1 \\
\end{array}$ \\
\hline V1 & 398 & 1736 & 4666 & $\begin{array}{c}0.856 \\
9\end{array}$ & 0.4714 & $\begin{array}{c}0.485 \\
8\end{array}$ \\
\hline $\mathrm{V}_{2}$ & 4647 & 3134 & 0.5126 & $\begin{array}{c}0.898 \\
4 \\
\end{array}$ & 0.444 & $\begin{array}{c}0.447 \\
1 \\
\end{array}$ \\
\hline $\mathrm{V}$ & 943 & 0054 & 4817 & $\begin{array}{c}0.900 \\
7 \\
\end{array}$ & 0.3973 & $\begin{array}{c}0.474 \\
4 \\
\end{array}$ \\
\hline V4 & 015 & 743 & 579 & $\begin{array}{c}0.952 \\
2\end{array}$ & 0.3881 & $\begin{array}{c}0.309 \\
9\end{array}$ \\
\hline V5 & 184 & 3927 & 4615 & 0.946 & 51 & $\begin{array}{c}0.381 \\
8 \\
\end{array}$ \\
\hline $\mathrm{A} 1$ & 1796 & 4406 & 3752 & $\begin{array}{c}0.305 \\
7 \\
\end{array}$ & 9151 & $\begin{array}{c}0.501 \\
4 \\
\end{array}$ \\
\hline & & 324 & 394 & 0.305 & 9148 & $\begin{array}{c}0.503 \\
5\end{array}$ \\
\hline PA3 & 532 & 5667 & 0.4957 & $\begin{array}{c}0.318 \\
3 \\
\end{array}$ & 8733 & $\begin{array}{c}0.574 \\
7 \\
\end{array}$ \\
\hline & 5 & 55 & 09 & $\begin{array}{c}0.336 \\
5 \\
\end{array}$ & 361 & 0.543 \\
\hline PA5 & 0.5663 & 0.4963 & 0.4506 & $\begin{array}{c}0.366 \\
2\end{array}$ & 9431 & $\begin{array}{c}0.559 \\
5\end{array}$ \\
\hline INT1 & 307 & 0.3365 & 0.3022 & $\begin{array}{c}0.356 \\
6 \\
\end{array}$ & 0.5565 & $\begin{array}{c}0.927 \\
1 \\
\end{array}$ \\
\hline INT2 & 2 & 0.8184 & 0.3837 & $\begin{array}{c}0.352 \\
6 \\
\end{array}$ & 0.5577 & $\begin{array}{c}0.951 \\
2 \\
\end{array}$ \\
\hline INT3 & 3427 & 0.3603 & 0.3717 & $\begin{array}{c}0.305 \\
4 \\
\end{array}$ & 0.5742 & $\begin{array}{c}0.960 \\
2 \\
\end{array}$ \\
\hline INT4 & 0.4996 & 0.3634 & 0.3231 & $\begin{array}{c}0.495 \\
3 \\
\end{array}$ & 0.5442 & $\begin{array}{c}0.941 \\
7 \\
\end{array}$ \\
\hline INT5 & 0.3922 & 0.8022 & 0.3164 & $\begin{array}{c}0.324 \\
9\end{array}$ & 0.539 & $\begin{array}{c}0.938 \\
9\end{array}$ \\
\hline
\end{tabular}

Table 3 reports the outcomes for AVE, composite reliability and Cronbach's alpha. According to Lee \& Kozar, 2008, composite reliability are more than suggested value of 0.7 . For convergent validity to be accepted, a threshold value of 0.5 is measure (Fornell \& Larcker, 1981). Form the table AVE is accepted. The Cronbach alpha for all variables are greater the suggested value of 0.6 , deducing the battery items representing the constructs possessing a high internal consistency.

Table 3: AVE, Composite reliability, Cronbach's alpha

\begin{tabular}{cccc}
\hline Variable & AVE & $\begin{array}{c}\text { Composite } \\
\text { Reliability }\end{array}$ & $\begin{array}{c}\text { Cronbachs } \\
\text { Alpha }\end{array}$ \\
\hline ATD & 0.792 & 0.9499 & 0.9335 \\
INT & 0.891 & 0.9761 & 0.9694 \\
PA & 0.841 & 0.9634 & 0.9524 \\
BC & 0.855 & 0.9673 & 0.9577 \\
\hline
\end{tabular}

\begin{tabular}{cccc} 
V & 0.831 & 0.9608 & 0.9487 \\
SBN & 0.798 & 0.9517 & 0.9365 \\
\hline
\end{tabular}

Table 4 present the outcome of discriminant validity in which as discovered in the analysis, with the suggested value of 0.7, AVE for all construct are accepted (Fornell \& Larcker, 1981), meeting discriminant validity.

Table 4: Discriminant validity

\begin{tabular}{ccccccr}
\hline Variabl & & & & & & \\
e & ATD & INT & PA & BC & V & SBN \\
ATD & $\mathbf{0 . 8 8 9 8 9}$ & & & & & \\
& & $\mathbf{0 . 9 4 3 9}$ & & & & \\
INT & 0.7837 & $\mathbf{3}$ & & & & \\
PA & 0.5605 & 0.5873 & $\mathbf{0 . 9 1 6 8}$ & & & \\
& & & 0.467 & & & \\
BC & 0.7535 & 0.784 & 9 & $\mathbf{0 . 9 2 4 9}$ & & \\
& & & 0.793 & 0.637 & & \\
V & 0.7297 & 0.7704 & 7 & 2 & $\mathbf{0 . 9 1 2}$ & \\
& & & 0.528 & 0.769 & 0.761 & $\mathbf{0 . 8}$ \\
SBN & 0.789 & 0.823 & 7 & 2 & 4 & $\mathbf{9}$ \\
\hline
\end{tabular}

\section{B. Structural Model Analysis}

Table 5 presents the outcomes of the structural analysis. Statistically, attitude, subjective norm, perceived behavioural control, and Perceived vicegerency is significantly related to the adoption of Islamic leadership style among Malaysian accountants. Of the five hypothesized relationships, only perceived accountability has an insignificant relationship to the adoption of Islamic leadership style, implying the null hypothesis is not rejected. In other words, the relationship between perceived accountability and the intention is not statistically significant. Table 5 provides the details.

Table 5: Structural analysis

\begin{tabular}{c|c|l|c}
\hline Pathway & $\operatorname{Beta}(\beta)$ & $t$-value & Supported \\
\hline $\begin{array}{c}\text { ATD-->IN } \\
\text { T }\end{array}$ & 0.1568 & 2.456 & Yes \\
\hline $\begin{array}{c}\text { SBN-->IN } \\
\text { T }\end{array}$ & 0.2921 & 3.3164 & Yes \\
\hline BC-->INT & 0.2796 & 3.0587 & Yes \\
\hline V-->INT & 0.2309 & 2.1011 & Yes \\
\hline PA-->INT & 0.0309 & 0.3496 & No \\
\hline
\end{tabular}

From the above table showed, it is conclude that there are a significant relationship between attitudes and adoption of Islamic leadership style among Malaysian accountants $((\beta=.157, p<0.01)$. This results is in tandem with a research study done by Mester et al. (2003) who reported that there is a positive relationship between leadership style and employee attitudes and behavior.

The results further suggest that subjective norms $(\beta=.292$, $\mathrm{p}<0.01)$ are significant predictors of Malaysian accountants in adoption of Islamic leadership style. This is supported by a study done by Almoharby \& Neal, (2013) who found that Prophet Muhammad (PBUH) is not just a historical figure to Muslims, but is the eternally current exemplar of good governance and leadership.

Results of the study also reports that perceived behavior controls $((\beta=.280$, $\mathrm{p}<0.01)$ are significantly 
related to the Islamic leadership style adoption and this is proved by the findings obtained from Monjur, (2010) who reported that in the era where Muslims in the world experiencing and undergoing resurrection, more and more leaders from the Islamic society rise, and play a larger role globally and this is very important for the world, including non-Muslims, to acknowledge this fact.

From the study, perceived vicegerency $(\beta=.231, \mathrm{p}<0.01)$ is also found to be significantly related to adoption of Islamic leadership style and Senam et al. (2018) stated that with regard to man as vicegerent (khalifah), Islamic values that would lead to a good leadership.

Of all the variables studied, only perceive accountability is found to be insignificant to adoption of Islamic leadership style among Malaysian accountants. One of the reasons is because the composition of respondent is mixed up, covering the $42.2 \%$ of non-Muslims while the rest is Muslims. Malaysian government practice so called an Islamic administration values. Thus including non-Muslims, they need to acknowledge the fact that some of the systems used in Malaysia are Islamic and this study is done to Islamize the way of leading people.

\section{CONCLUSION AND FUTURE RESEARCH}

In conclusion, most of the accountants believed that attitudes are very important in shaping particular behavior. This is also followed by subjective norms, $\mathrm{n}$ vicegerency. Hameed and Yaya (2005) discussed that Muslim's accountants especially are expected to always act in a manner that are compliant to Shariah laws. This is because accountants are a leader too as they have to make decision in making sure that the financial reports are well presented with no errors. In order to make sure they are complying with all the Shariah laws, they need to put themselves as a vicegerent for which they need to believed that whatever they do are for the sake of Allah.

One of the limitations of this study is the inclusion of non-Muslims respondents in which $42 \%$ that effect the findings of the study. Secondly this study does not reported HTMT source because of the use of Smart PLS 2 has no such features and according to (Churchill, 1979) factors analysis is enough for discriminant validity.

In future, it is suggested that more balanced and accurate selection of non-Muslims respondents can be directed to extend the findings. Not just that the works also intense to utilize a more advanced software to scrutinize the data.

\section{REFERENCES}

[1] Ab Rahim, F., \& Amin, H. (2011). DETERMINANTS OF ISLAMIC INSURANCE ACCEPTANCE: AN EMPIRICAL ANALYSIS. International Journal of Business and Sociaety, 12(2), 37-54.

[2] Adnan, N. and Md Nordin, S. (2017). The impacts and visions of the green fertilizer technologies (GFT) Adoption behaviour among Malaysian paddy farmers. World Journal of Science, Technology and Sustainable Development, 14(4), 336-354.

[3] Ahmad, K., \& Fontaine, R. (2011). Islamic Leadership At the International. International Journal of Economics, Management and Accounting, 2(2), 121-135.

[4] Ahmad, K., \& Ogunsola, O. K. (2011a). An empirical assessment of islamic leadership principles. International Journal of Commerce and Management, 21(3), 291-318.
[5] Ahmad, K., \& Ogunsola, O. K. (2011b). An empirical assessment of islamic leadership principles. International Journal of Commerce and Management, 21(3), 291-318.

[6] Ahmed, A., Farzeen, M., \& Anwar, N. (2017). Relationship among Job Satisfaction, Attitude towards work And Organizational Commitment. Journal of Management Info, 4(3), 1-4.

[7] Ahmed Haj Ali, A. R., Bin Noordin, K., \& Achour, M. (2018). The Islamic approach of obligations in mutual relations between employee and employer. International Journal of Ethics and Systems, 34(3), 338-351. https://doi.org/10.1108/ijoes-12-2017-0227

[8] Ajzen, I. (1991). The Theory of Planned Behavior. Organizational Bhevaior and Human Decision Process, 50, 179-211.

[9] Alam, S. S., Mohd, R., \& Hisham, B. (2011). Is religiosity an important determinant on Muslim consumer behaviour in Malaysia? Journal of Islamic Marketing, 2(1), 83-96.

[10] Alam, S. S., \& Sayuti, N. M. (2011). Applying the Theory of Planned Behavior (TPB) in $\langle\mathrm{IT}\rangle$ halal $</ \mathrm{IT}\rangle$ food purchasing. International Journal of Commerce and Management, 21(1), 8-20.

[11] Alexakis, G. (2011). Transcendental leadership: The progressive hospitality leader's silver bullet. International Journal of Hospitality Management, 30(3), 708-713.

[12] Almoharby, D., \& Neal, M. (2013). Clarifying Islamic perspectives on leadership. Education, Business and Society: Contemporary Middle Eastern Issues, 6(3-4), 148-161.

[13] Amin, H., Abdul-Rahman, A. R., \& Abdul-Razak, D. (2013). An integrative approach for understanding Islamic home financing adoption in Malaysia. International Journal of Bank Marketing, 31(7), 544-573.

[14] Amin, H., \& Abdul-razak, D. (2014). An integrative approach for understanding Islamic home financing adoption in Malaysia.

[15] Ang, M. C. H., Ramayah, T., \& Amin, H. (2015). A theory of planned behavior perspective on hiring Malaysians with disabilities. Equality, Diversity and Inclusion, 34(3), 186-200.

[16] Asnawi, N., Sukoco, B. M., \& Fanani, M. A. (2018). Halal products consumption in international chain restaurants among global Moslem consumers. International Journal of Emerging Markets, 13(5), 1273-1290.

[17] Ather, S. M., \& Sobhani, F. A. (2008). Managerial Leadership : An Islamic Perspective. Iiuc Studies, 4(December 2007), 7-24.

[18] Ather, S. M., \& Sobhani, F. A. (2009). Managerial Leadership: An Islamic Perspective. IIUC Studies, 4(April), 7-24.

[19] Awa, H. O., Ojiabo, O. U., \& Emecheta, B. C. (2015). Integrating TAM, TPB and TOE frameworks and expanding their characteristic constructs for e-commerce adoption by SMEs. Journal of Science and Technology Policy Management, 6(1), 76-94.

[20] Beekun, R. I. (2012). Character centered leadership: Muhammad (p) as an ethical role model for CEOs. Journal of Management Development, 31(10), 1003-1020.

[21] Beekun, R. I., \& Badawi, J. (1999.). LEADERSHIP : A N ISLAMIC PERSPECTIVE.

[22] Churchill, G. A. (1979). A Paradigm for Developing Better Measures of Marketing Constructs. Journal of Marketing Research, 16(1), 64-73.

[23] Claes Fornell, \& Larcker, D. F. (1981). Evaluating Structural Equation Models with Unobservable Variables and Measurement Error: A Comment. Journal of Marketing Research, 18(1), 39-50.

[24] Flowers, E. P., Freeman, P., \& Gladwell, V. F. (2017). The development of three questionnaires to assess beliefs about green exercise. International Journal of Environmental Research and Public Health, 14(10).

[25] Gopi, M., \& Ramayah, T. (2007). Applicability of theory of planned behavior in predicting intention to trade online: Some evidence from a developing country. International Journal of Emerging Markets, 2(4), 348-360.

[26] Habib Rana, M., \& Shaukat Malik, M. (2016). Human resource management from an Islamic perspective: a contemporary literature review. International Journal of Islamic and Middle Eastern Finance and Management, 9(1), 109-124.

[27] Hage, J., \& Posner, B. Z. (2015). Religion, religiosity, and leadership practices: An examination in the Lebanese workplace. Leadership and Organization Development Journal, 36(4), 336-412.

[28] Hsiao, C.-H., \& Tang, K.-Y. (2014). Explaining undergraduates' behavior intention of e-textbook adoption. Library Hi Tech, 32(1), $139-163$.

[29] Jin, B., \& Kang, J. H. (2011). Purchase intention of Chinese consumers toward a US apparel brand: A test of a composite behavior intention model. Journal of Consumer Marketing, 28(3), 187-199. 
[30] Kannaiah, D., \& Kumar, N. S. (2017). An Urgent Need for Ethics Education for Accountants. Issues In Social And Environmental Accounting, 3(1), 88.

[31] Keller, A. C., Smith, K. T., \& Smith, L. M. (2007). Do gender, educational level, religiosity, and work experience affect the ethical decision-making of U.S. accountants? Critical Perspectives on Accounting, 18(3), 299-314.

[32] Kumar, A. (2017). Extended TPB model to understand consumer "selling" behaviour: Implications for reverse supply chain design of mobile phones. Asia Pacific Journal of Marketing and Logistics, 29(4), 721-742.

[33] Lee, Y., \& Kozar, K. A. (2008). An empirical investigation of anti-spyware software adoption: A multitheoretical perspective. Information and Management, 45(2), 109-119.

[34] Low, M., Davey, H., \& Hooper, K. (2008). Accounting scandals, ethical dilemmas and educational challenges. Critical Perspectives on Accounting, 19(2), 222-254.

[35] Monjur, M. (2010). Characteristics of Leadership: Islamic perspective Muslim-Christian relations in Bangladesh View project. (June 2010).

[36] Norazah, M.S., \& Norbayah, M. S. (2015). Consumers' environmental behaviour towards staying at a green hotel: Moderation of green hotel knowledge. Management of Environmental Quality: An International Journal, 26(1), 103-117.

[37] Norazah, Mohd Suki, \& Abang Sulaiman, A. S. (2016). Does Halal image strengthen consumer intention to patronize Halal stores?: Some insights from Malaysia. Journal of Islamic Marketing, 7(1), 120-132.

[38] Reza Jalilvand, M., \& Samiei, N. (2013). The impact of electronic word of mouth on a tourism destination choice. Internet Research, 22(5), 591-612.

[39] Salie, A. (2009). Servant-minded leadership and work satisfaction in Islamic organizations: A correlational mixed study. Dissertation Abstracts International, A: The Humanities and Social Sciences, 70 (November), 1349.

[40] Wang, G., Dou, W., \& Zhou, N. (2008). Consumption attitudes and adoption of new consumer products: a contingency approach. European Journal of Marketing, 42(1/2), 238-254.

[41] Wynne W. Chin. (2011). Handbook of PLS. In Methods (p. 627).

\section{AUTHORS PROFILE}

Nurjeehan Binti Ayub, I am from Labuan Faculty of International Finance, Universiti Malaysia Sabah Kampus Antarabangsa Labuan (UMSKAL), Jalan Sungai Pagar, 87000 Wilayh Persekutuan Labuan Malaysia., my area of interest is international finance and management.

Hanudin Amin, I am from Labuan Faculty of International Finance, Universiti Malaysia Sabah Kampus Antarabangsa Labuan (UMSKAL), Jalan Sungai Pagar, 87000 Wilayh Persekutuan Labuan Malaysia. my area of interest is international finance and management.

Fitriah Ab Rahim, Labuan Faculty of International Finance, Universiti Malaysia Sabah Kampus Antarabangsa Labuan (UMSKAL), Jalan Sungai Pagar, 87000 Wilayh Persekutuan Labuan Malaysia. my area of interest is international finance and management. 